\title{
Applying Critical Thinking Skills to Improve Students’ Essay Writing Skills
}

\author{
Nguyen Thi Kieu Thu, Ph.D, Vo Tran Minh Hieu* \\ Ho Chi Minh City University of Technology (HUTECH), Vietnam
}

*Corresponding Author: Vo Tran Minh Hieu, Ho Chi Minh City University of Technology (HUTECH), Vietnam

\begin{abstract}
Critical thinking skills have been so far believed to be the solid background for learning a foreign language. Writing, which makes students analyze, think and successfully create products, surely needs indispensable critical thinking skills. Thus, applying critical thinking skills in English language teaching (ELT) is the content of this study. The current study aimed to explore the effectiveness of the teaching method applying critical thinking skills on the English majors at Ho Chi Minh City University of Social Sciences and Humanities (USSH) both improvement on the skills and attitudes toward the teaching method. With a quantitative mixed research, the study found that the teaching method actually improved students' essay writing ability when the paired-sample t-test stated that the difference between the assignment 1 score set, the pre-test, and the final exam score set, the post-test, was statistically significant with Cohen's $d$ effect size of 0.18. The regression analysis statistically significantly resulted that students highly appreciated the teaching method with the strong effects were put on the global aspects of writing skills, Coherence and Cohesion, Organization and Task response in this study, but not on the surface aspects, Grammar and Sentence structure and Vocabulary. (193 words)
\end{abstract}

Keywords: Critical Thinking Skills; ELT; Essay Writing Skills; Students' attitude

Abbreviations: EF: Faculty of English Linguistics and Literature;USSH: Ho Chi Minh City University of Social Sciences and Humanities

\section{INTRODUCTION}

In 1950s, Bloom created a taxonomy in order to promote higher forms of thinking in education, referring to three main domains of learning: cognitive, affective, and psychomotor. Of the three domains, the cognitive domain involves knowledge and the development of intellectual skills (Bloom, 1956, in Anderson \&Krathworhl, 2001). This domain includes the recall or recognition of specific facts, procedural patterns, and concepts that serve in the development of intellectual abilities and skills with six major categories of - from the simplest to most complex ones - knowledge (recalling the information), comprehension or understanding, application, analysis, synthesis, and evaluation. Among these six stages, the two first stages can be seen as the descriptive thinking, and the remaining stages are the critical thinking. According to Krathwohl, Bloom and Masia (1973), the affective domain in learning skills includes the manner in which students deal with things emotionally, such as feelings, values, appreciation, enthusiasms, motivations, and attitudes. The third domain in Bloom's taxonomy mentions to psychomotor learning, which relates to learners' manual or physical skills. However, while the cognitive and affective domains are intensively produced as an elaborate compilation in education environments, the psychomotor domain is usually ignored (Wilson, 2018).

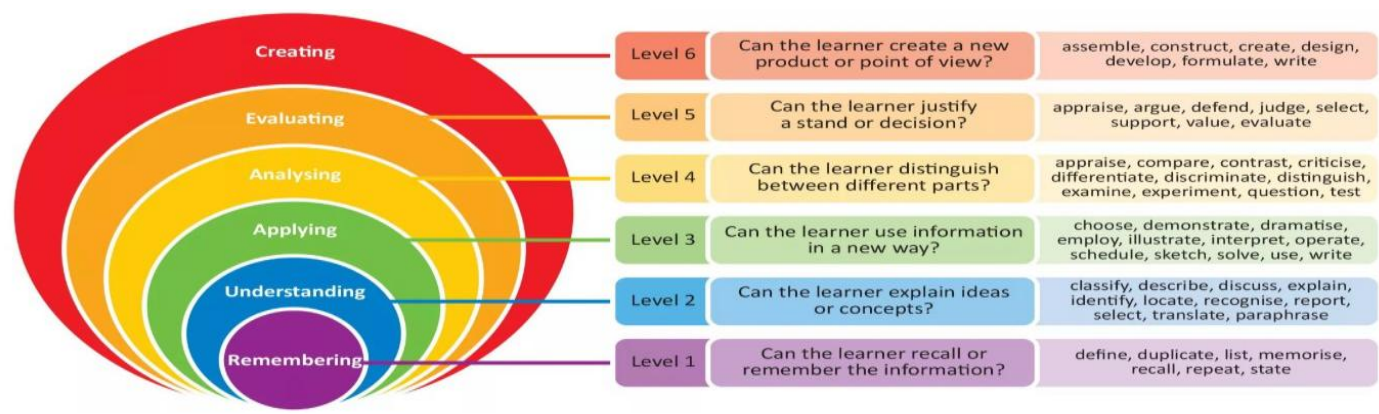

Figure1:Bloom's revised taxonomy on learning 
(Source: https://www.niallmcnulty.com/2017/11/blooms-digital-taxonomy/)

At the beginning of the millennium, Bloom's taxonomy has been revised by Anderson and his colleagues, in which the most important change is rearranging the two top categories of "synthesis" and "evaluation" to "evaluate" and "create" as in the following figure.

Owing to the truth that the foremost purpose of human beings' activity is to create their own new products, Bloom's revised taxonomy gradually has replaced for the original. The teaching method mentioned in this study has been absolutely a trend.

Academic writing skill, which is considered as a token on a good indicator in language learning process (Benjamin \& Chun, 2003), therefore, cements tightly to critical thinking skills. Theoretically, writing skill is a specific ability and an important part of communication to share information, message, ideas, or thoughts in grammatically correct sentences. In this aspect, students from nonEnglish countries, especially from Confucius-heritage countries culturally, have a way to develop pieces of academic writing different from English style (Grabe\& Kaplan, 1996; Vyncke, 2012; andGuo, 2013). Moreover, as pointed by many scholars, critical thinking is less practiced in Asian countries, in which one is Vietnam (Davidson, 1998; and Loh\&Teo, 2017) while Mahyuddin et al. (2004) showed that language learners who have developed critical thinking skills in writing have better results than other learners who have not apply techniques in critical thinking skills.

Consequently, this studyis conducted to explore the effectiveness of applying critical thinking skills into teaching English-majored students at the Faculty of English Linguistics and Literature USSH (EF, hereafter).The study pursued to address the following two research questions:

Research Question 1:Do the EF students improve their essay writing skills with the application of critical thinking skills?

Research Question 2: How is the EF students' attitude toward the teaching method applying critical thinking skills in learning essay writing?

\section{AIMS AND OBJECTIVES OF THE STUDY}

The aim of the present study is to clarify several aspects of critical thinking on essay writing of EF students by sharing both theoretical and practical contributions about critical thinking in teaching academic writing. Besides, this study helps the EF students to think more effectively and improve their essay writing skills by applying the teaching techniques they have been taught.

The specific objectives of this study are:

- To examine the improvement of EF students in their writing ability from the beginning to the end of the course after applying critical thinking skills;

- To investigate how the EF students self-evaluate their improvement in terms of the components of Coherence and Cohesion, Grammar and Sentence structures, Organization, Task response, and Vocabulary.

- To explore the attitudes ofEF students toward the application of critical thinking skills in teaching and learning essay writing.

\section{THEORETICAL AND CONCEPTUAL FRAMEWORK}

Theoretically, the teaching method applied in the course based on Bloom's revised taxonomy. All teaching techniques used in the course aimed to instruct students to remember the learned lessons, to understand and apply these lessons to be able to effectively analyze and to successfully evaluate the paper composed by their classmates and to academically create their own pieces of writing. The typical lesson plan on Appendix 1 displays the application of Bloom's revised taxonomy into the teaching method. Each objective in the lesson plan has a concrete purpose extracted from Bloom's revised taxonomy.

Based on the theoretical background aforementioned, a study has beenconceptually conducted with two quantitative dimensions to examine the students' improvement, and to explore the students' selfevaluation on their improvement on essay writing skills after the course with five important factors of essay writing skills, Coherence and Cohesion, Grammar and Sentence Structure, Organization, Task responses, and Vocabulary. 


\section{Method}

In this study, pair-samples t-tests are used to examine the different between the results of the pre-test and the post-test. This statistical tool is used to analyze the data to answer the research question 1. Concurrently, the statistical method of regression analysis is resorted to analyze the data collected from a questionnaire to explore students' attitude towards the teaching method as well as their selfevaluation on their improvement with essay writing skills. This statistical tool is used to analyze the data collected from the questionnaire to answer the research question 2.

\subsection{Participants}

Totally, 356 English-majored studentswere involved in the sample for paired-samples t-tests in the study. These students consist of 272 students of Second-degree program and 84 students of Transfer program at USSH in different academic years. To collect the data for the regression analysis, a questionnaire has been emailed to all students already learned with the teaching method. 273 students, consisting of 212 from Second-degree Program and 61 from Transfer Program, responded the email and provided the relevant data for the study.

\subsection{Instruments}

A seven-option Likert scale questionnaire, which is attached in Attachment 2, is used to query students' attitudes towards the teaching method as well as their satisfaction towards their improvement on essay writing skills. The questionnaire has 30 items, in which six items, Item \#02, Item \#07, Item \#16, Item \#19, Item \#23, and Item \#28, relates to the component of Coherence and Cohesion, seven items, Item \#04, Item \#06, Item \#11, Item \#15, Item \#22, Item \#24, and Item \#30, relate to the component of Grammar and Sentence structures, seven items, Item \#01, Item \#05, Item $\# 10$, Item \#14, Item \#21, Item \#25, and Item \#29, relate to the component of Organization, six items, Item \#03, Item \#09, Item \#13, Item \#17, Item \#29, and Item \#27, relate to the component of Task responses, and four items, Item \#08, Item \#12, Item \#18, and Item \#26, relate to the component of Vocabulary. The last item of the questionnaire is used as the dependent variable when analyzing the data with regression analysis. This item queries students' attitudes towards the teaching method.

The Assignment 1 and the final exam of each class are used as the instrument for the paired-samples t-tests in the study. To remove the control variable, only the scores relating to the essay are taken into analyzing.

\subsection{Data collection}

The score sets used to examine the students' improvement on essay writing skills are provided by the lecturer, who directly has applied critical thinking skills into teaching essay writing skills and also is the rater of the paper. These score sets also have been officially submitted to the Faculty of English Linguistics and Literature of Ho Chi Minh University of Social Sciences and Humanities while the responses to the questionnaire are send to the researcher via email when all of these students already stopped learning the subject.

\subsection{Data Analysis}

A paired-samples t-test is used to determine whether the mean difference between the two score sets of the observations in question. In this study, the observations were taken into analysis are the scores that the students marked for the essay in their assignment one and the scores that the students marked for the essay in their final exams. Thus, used in this study, the paired-samples t-test provides the results to answer the research question 1.

With the data collected from the questionnaire, multiple regression analysis is used to estimate the relationships between the dependent variable, which is the students' satisfaction toward the teaching technique applied, and the predictor variables, which are the students' self-evaluation on their improvement in terms of the different components in essay writing skills. This means of statistics is used to help the researcher understand how the typical value of the dependent variable changes when any one of the independent variables in question is varied while the other variables are held fixed. 


\section{ReSUlts}

\subsection{Results from the Paired-Samples T-Test Analysis}

Analyzing the difference between the scores of Assignment 1s and Final exams, the paired-samples ttest displays the difference with sample size is statistically significant with the $t$ coefficient of minus 3.030 and the degree of freedom of 355, the Sig. (2-tailed) is lower than the probability $p$ with only 0.003 and the Cohen's d effect size is 0.18, expressing that around 56\% of Assignment 1 score set are lower than the average of the Final exams score set.

Table1: Paired-samples t-test results for students' assignment $1 \mathrm{~s}$ and final exams

\begin{tabular}{|l|l|l|l|l|l|l|l|l|}
\hline & Mean & $\begin{array}{l}\text { Std. } \\
\text { Deviation }\end{array}$ & \multirow{2}{*}{$\begin{array}{l}\text { Std. Error } \\
\text { Mean }\end{array}$} & $\begin{array}{l}\text { 95\% Confidence Interval } \\
\text { of the Difference }\end{array}$ & $\mathrm{t}$ & df & $\begin{array}{l}\text { Sig. (2- } \\
\text { tailed) }\end{array}$ \\
\cline { 1 - 4 } $\begin{array}{l}\text { Assignment 01s - } \\
\text { Final Scores }\end{array}$ & -.2739 & 1.7055 & .0904 & -.4516 & -.0961 & -3.030 & 355 & .003 \\
\hline
\end{tabular}

\subsection{Results from the Regression Analysis}

Regression analysis with linear approach and with the extracting method of Varimaxis used to extract the principal components from the data collected with the research questionnaire. To make sure the data collected are reliable for further analysis, the mean of reliability statistics is used to check if the internal correlation of the respondents with each component in question reaches the minimum Cronbach's alpha of .700 and all item-total correlation coefficients for the items in each component are equal or higher than .300 as suggested by de Vaus (2002). Results of the reliability statistics prove that the five principal components extracted from the responses are reliable for further analysis with the Cronbach's alpha coefficients are .854 for Coherence and Cohesion component,. 747 for Grammar and Sentence structure component, .867 for Organization component, .881 for Task response component, and .807 for Vocabulary component.

The regression analysis between the five aforementioned components and the dependent variable produces the KMO test coefficient of .611 and Bartlett's test of sphericity Sig. value of .000 , much lower than the probability of 0.050 , proving that the data is valid for further analysis.Also, the Cumulative \% of Rotation Sums of Squared Loading of the analysis is 60.04\%, higher than the requirement of 50\% as suggested by Gerbing and Anderson (1988), Hair et al. (1988). The factor loadings of all items taken into the analysis are also higher than the requirement of .300, expressing that the analysis is both valid and reliable.

The regression analysis, then, results in three tables. First, the table model summary produces a rather high correlational coefficient $R$ with 0.739 , indicating a high relationship between the predictor variables and the dependent variable, and a high effect size correlation of $R^{2}$ with 0.546 , expressing $56.60 \%$ of the total variation in the dependent variable, which was the students' attitudes towards the teaching method, could be explained by the five components of the essay writing skills. The adjusted $R^{2}$ indicates that the model is strong when it has a high coefficient of 0.546 , corresponding to $54.60 \%$ of the variation explained by only the predictor variables that actually affect the dependent variable, leaving $43.40 \%$ of the variation of the dependent variable is affected by other factors that were out of the researchers' expectation.

Table2: Model summary for the regression model

\begin{tabular}{|l|l|l|l|l|}
\hline Model & R & R Square & Adjusted R Square & Std. Error of the Estimate \\
\hline 1 & $.739^{\mathrm{a}}$ & .546 & .538 & .505 \\
\hline
\end{tabular}

a. Predictors: (Constant), REGR factor Vocabulary, REGR factor Grammar \& Sentence structure, REGR factor Task response, REGR factor Coherence \& Cohesion, REGR factor Organization

Table ANOVA (Analysis of Variables) of the exploratory factor analysis produces the Sig. value much lower than the requirement of 0.05 with only 0.000 from $\mathrm{F}(5,267)=64.228$, indicating that the regression model predicts the dependent variables well and the results are statistically significant.

Table3: ANOVA (Analysis of Variables) of the regression model

\begin{tabular}{|l|l|l|l|l|l|l|}
\hline Model & Sum of Squares & df & Mean Square & F & Sig. \\
\hline \multirow{5}{*}{1} & Regression & 81.832 & 5 & 16.366 & 64.228 & $.000^{\mathrm{b}}$ \\
\cline { 2 - 7 } & Residual & 68.036 & 267 & .255 & & \\
\cline { 2 - 7 } & Total & 149.868 & 272 & & & \\
\hline
\end{tabular}


a. Dependent Variable: Students' attitudes towards the teaching method

b. Predictors: (Constant), REGR factor Vocabulary, REGR factor Task response, REGR factor Grammar, REGR factor Coherence, REGR factor Organization

Finally, table Coefficients of the linear regression analysis provides the necessary information to predict the changes of the dependent variable from the changes of five predictor variables in the study. The Sig. column expresses that the prediction based on the regression equation is statistically significant for all five components when the Sig. values all are lower than the probability $p \leq 0.05$.

Table4: Coefficients of the regression model

\begin{tabular}{|l|l|l|l|l|l|l|}
\hline \multicolumn{2}{|l|}{ Model } & \multicolumn{2}{l}{$\begin{array}{l}\text { Unstandardized } \\
\text { Coefficients }\end{array}$} & $\begin{array}{l}\text { Standardized } \\
\text { Coefficients }\end{array}$ & $\mathrm{t}$ & Sig. \\
\cline { 3 - 7 } \multicolumn{2}{|l}{1} & B & Std. Error & Beta & & \\
\hline \multirow{3}{*}{1} & (Constant) & 5.022 & .031 & & 164.377 & .000 \\
\cline { 2 - 7 } & REGR factor Organization & .396 & .031 & .533 & 12.935 & .000 \\
\cline { 2 - 7 } & REGR factor Coherence \& Cohesion & .258 & .031 & .347 & 8.427 & .000 \\
\cline { 2 - 7 } & REGR factor Task response & .247 & .031 & .333 & 8.078 & .000 \\
\cline { 2 - 7 } & REGR factor Grammar \& Sentence structure & .098 & .031 & .132 & 3.192 & .002 \\
\cline { 2 - 7 } & REGR factor Vocabulary & -.083 & .031 & -.112 & -2.717 & .007 \\
\hline
\end{tabular}

a. Dependent Variable: Students' attitudes towards the teaching method

With the constant of 5.002 , the values in $B$ column of unstandardized coefficients present the regression equation for the model as:

- Students' attitudes toward the teaching method $=5.002+(0.396 \mathrm{x}$ Organization $)+(0.258 \mathrm{x}$ Coherence \& Cohesion $)+(0.247$ x Task response $)+(0.098 \times$ Grammar \& Sentence structure $)+$ $(-0.083 \times$ Vocabulary).

\section{DISCUSSION}

The results produce from the paired-samples t-test and regression analysis have shown that the teaching method brought some benefits to students in their essay writing skills, especially with the global aspects. This finding is clearly consistent with many researchers' point of view. In general, the teaching method has statistically significant improved students' essay writing skills when the pairedsamples t-test displayed that students have quantitatively made a different of .2739 in average from the first day to the last day of the course. More importantly, analyzed by the regression analysis, the data collected from the questionnaire express that students have believed that the teaching method helps them improve their essay writing skills, especially with the global aspects of the skills, consisting Coherence and Cohesion component, Organization component and Task response component.

With the Coherence and Cohesion component, the respondents in the study state that they highly appreciate the teaching method when they felt being improved their essay writing skills with the aspects with $22.95 \%$ of the respondents state it is USUALLY true for them and $18.38 \%$ has the idea of it is OFTEN true. Especially, Item \#02, The teaching method forces me continue thinking more logical when developing an essay, and Item \#19, After the course, I gave up my habit of "beating about the bust" when developing an essay, reach an interesting percentage of the responses for the two items with the two last options of $24.91 \%$ and $24.91 \%$ for usually True and $15.02 \%$ and $13.19 \%$ for almost always True, respectively.

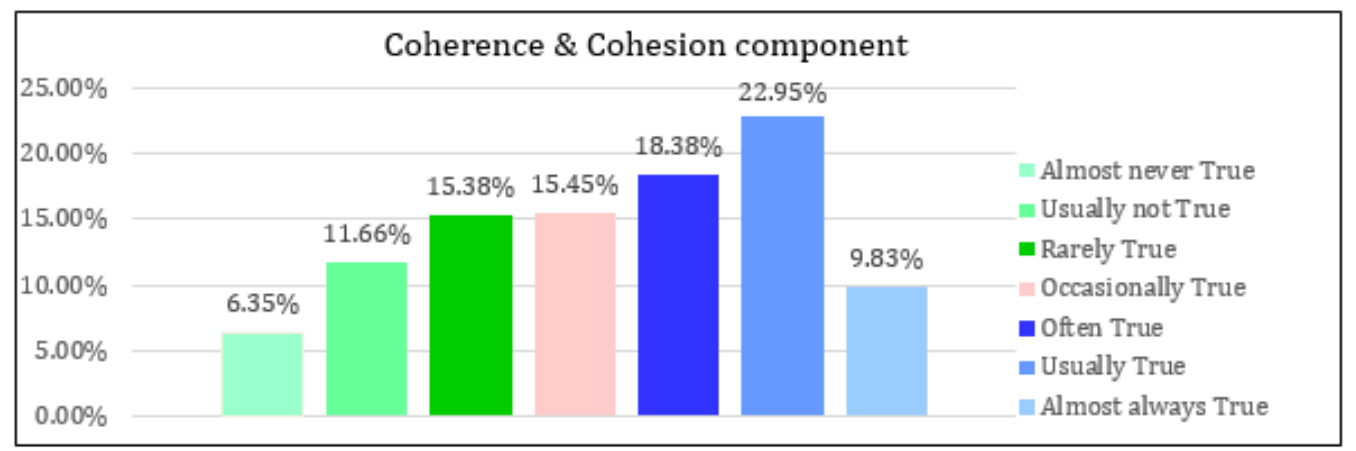

Figure2: Distribution of the students' responses in percentage with the component of Coherence and Cohesion 
The component of Task responses also observes a strong point of the teaching method when up to $51.34 \%$ of the respondentshave their positive ideas towards the effectiveness of the teaching method (21.25\% chose often True, $17.58 \%$ chose usually True, and $12.52 \%$ chose almost always True), compared to only $34.31 \%$ were on the negative side, concretely $9.65 \%$ chose almost never True, $11.36 \%$ chose usually not True, and $13.31 \%$ chose rarely True). Among seven choices of the responding scale, the two positive choices of often Trueand Usually True are the highest responses with $21.25 \%$ and $17.58 \%$, respectively.

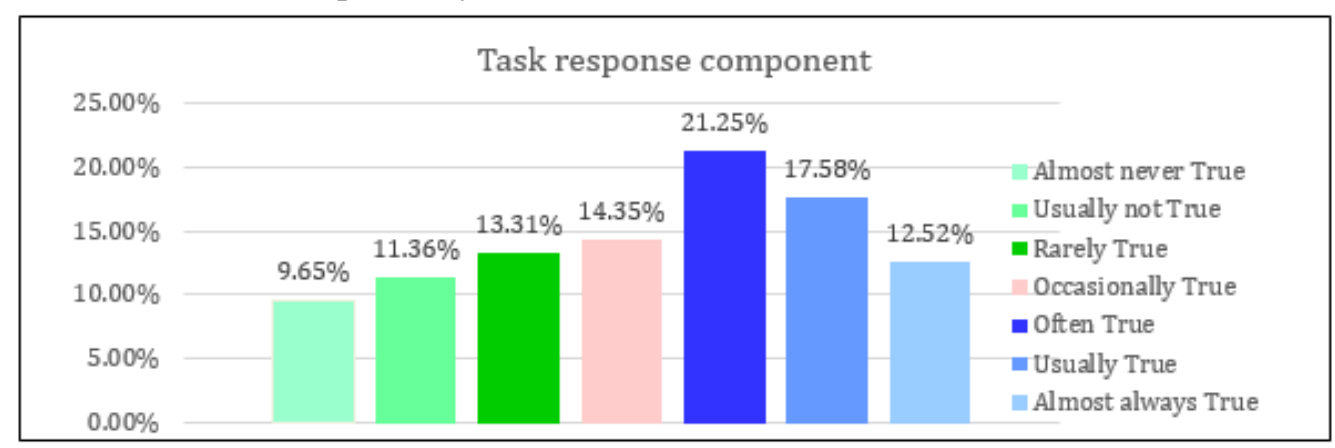

Figure3: Distribution of the students' responses in percentage with the component of Task response.

Remarkably, the component of Organization proves a strong point of the teaching method when a record of $32.86 \%$ of the respondents chose usually True and the second highest is of the option often True with $19.10 \%$ while the three first options on the negative side reach totally $19.784 \%$ (2.56\% for almost never True, $7.43 \%$ for usually not True, and $9.79 \%$ for rarely True). With the majority of the responses, $66.20 \%$, were ticked on positive side (from often True to almost always True), this component seems to be the most effective component of the teaching method on instructing student's essay writing skills.

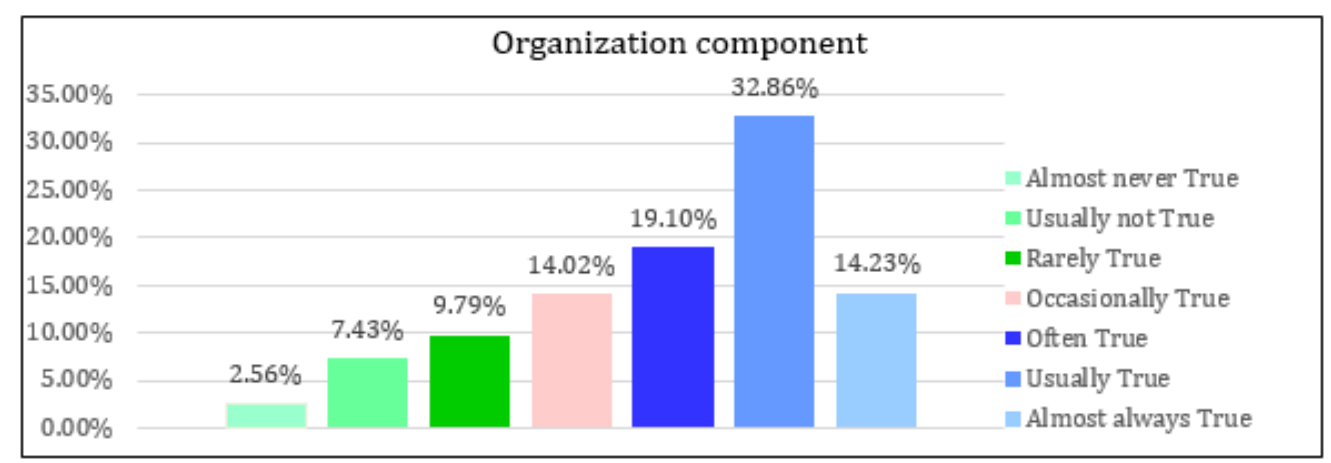

Figure4: Distribution of the students' responses in percentage with the component of Organization

However, two surface aspects of the essay writing, concretely the component of Grammar and Sentence structure and Vocabulary are not highly appreciated by the respondents. Relating to the component of Grammar and Sentence structure, even though the four last options of occasionally True, often True, usually True, and almost always True, with 67.29\%dominate over the negative side with $32.71 \%$. However, students seemed not much highly to appreciate the teaching method with this aspect when up to $24.86 \%$ of the respondents chose the option of occasionally True, the highest response to the component.

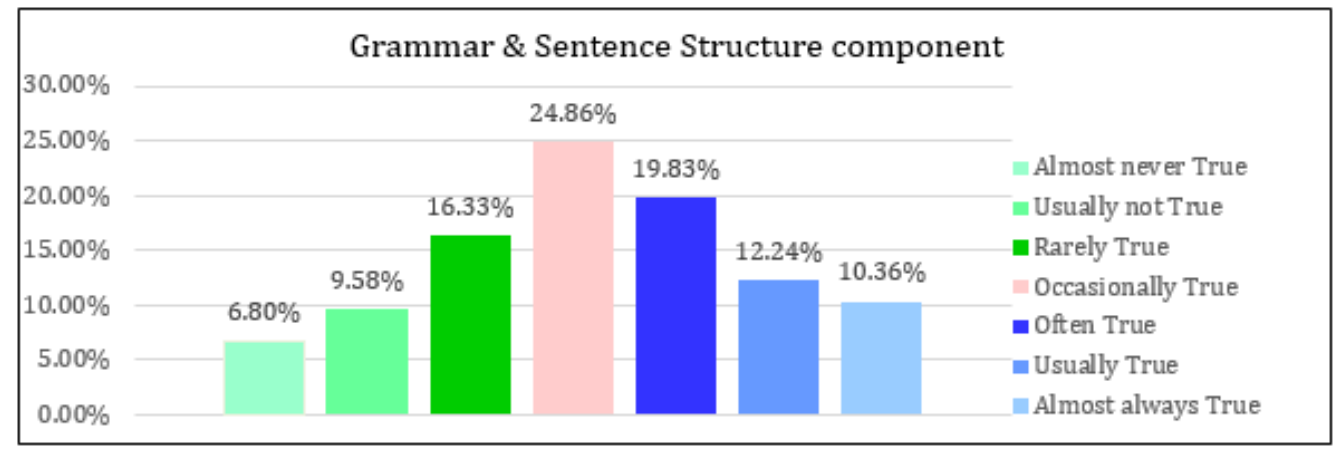

Figure5: Distribution of the students' responses in percentage with the component of Grammar and Sentence structure. 
The component of Vocabulary expresses a discrepancy among the respondents. Remarkably, the two most negative options get a concerned attention when they take a high percentage with $13.46 \%$ for the option almost never True and $14.84 \%$ for the option usually not True. More importantly, Item \#26, I focus more on using many syllable words than simple words, gets a record of negative ideas when up to $58.61 \%(24.18 \%, 24.54 \%$, and $9.89 \%$, in turn) of the students responded from almost never True to rarely True. However, the highest option still belongs to the positive side with the option often True reaches $20.70 \%$ while the neutral point of view of occasionally True is $19.78 \%$, coming the second place of the seven options. This discrepancy might come from a) the teaching method focus on using language accurately more than on improving students' volume of language used, and b) the course limited itself on the number of the topics developed; students, therefore, had some fields to improve their language used.

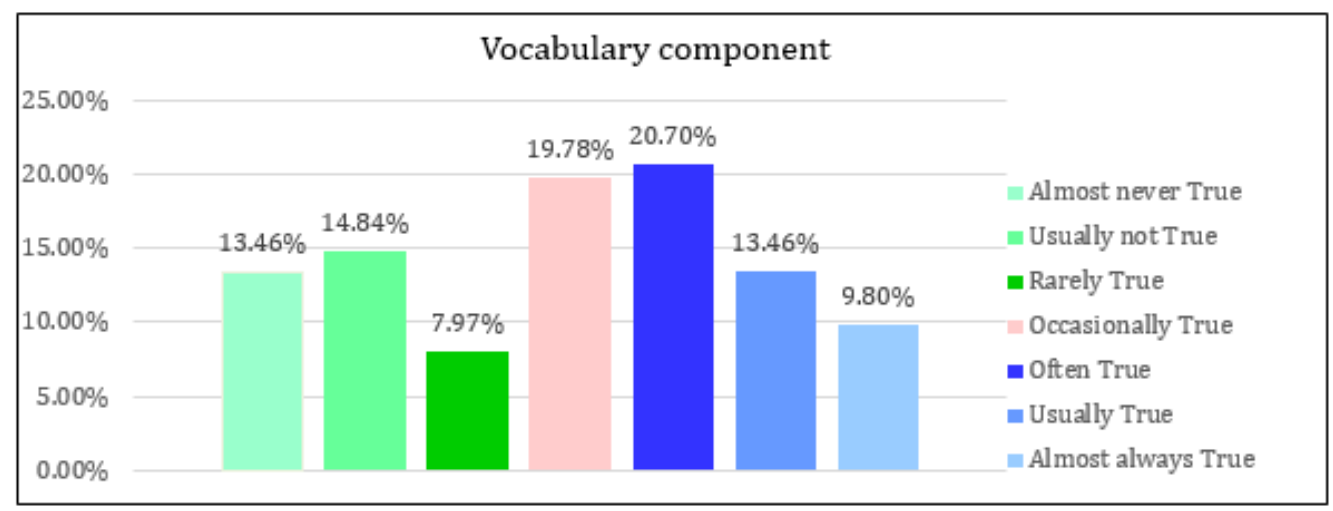

Figure6: Distribution of the students' responses in percentage with the component of Vocabulary.

Responding to the seven-option Likert scale which queries respondents their attitude toward the teaching method, only four options Rarely True, Occasionally True, Often True, and Usually True were chosen, the three remaining options had no choice from the respondents. Among these four options, the option Often True is completely dominant with $52.75 \%$, coming next is the option Usually True with $26.01 \%$, making the positive ideas completely prominent with $78.76 \%$. The negative attitude with the only option of Rarely True gets a very small portion of $2.56 \%$ while the neutral idea of Occasionally True reaches a modest part of $18.68 \%$. These portions clearly confirm that the teaching method was effective for these students on their essay writing skills.

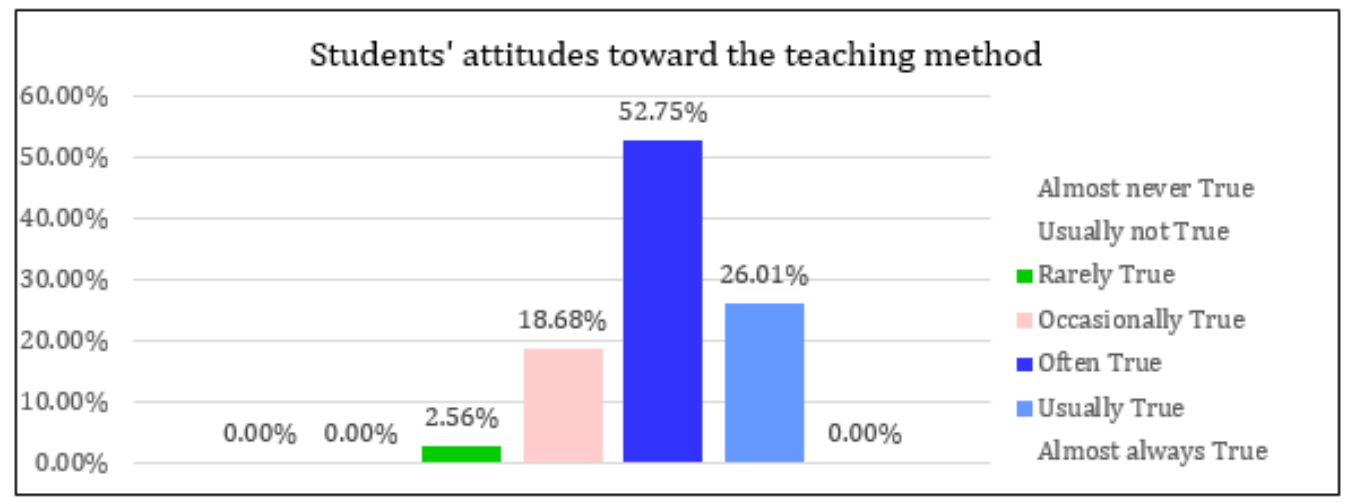

Figure7: Distribution of the students' attitudes toward the application of critical thinking skills in learning essay writing skills.

Based on the aforementioned analysis, the two research questions formulated were addressed. With the research question 1, the study finds that the students at USSH involved in the study have been improving their essay writing skills with the teaching method into which critical thinking skills are applied. The paired-samples t-test for the score set of assignment 1 and that of the final exams state that there is a statistically significant difference between the two score sets with the relation is around $18.63 \%$ of effect size, accounting for around $56 \%$ of the assignment $1 \mathrm{~s}$ scores is lower than the average of the final scores.

With research question 2, the study finds that two hundred and seventy-three respondents appreciate the advantages in essay writing skills that the teaching method brings to them. 


\section{CONCLUSiON}

The present study was designed to examine the students' improvement of their essay writing skill when the teaching method asked them to resort to their critical thinking skills and to investigate these students' perception towards the teaching method based on their improvement on the related components of the essay writing skills. The finding of the study is consonant to many researchers' points of view in the field. First of all, the paired-samples t-test proved that students' essay writing skills, in general, are statistically significantly improved. Secondly, after the course, students have believed that their essay writing skills have been improved when a dominant portion of $78.27 \%$ of the students in the study affirmed their improvement, in which $51.27 \%$ stated that the improvement is often True to them and $26.01 \%$ stated usually True while only $2.56 \%$ of the students thought in the opposite points of view. Especially, these improvements were put on the aspects of Organization, Coherence and Cohesion, and Task responses, the global aspects of academic writing, which are considered as the hinder for students from Confucius-heritage countries to successfully approach English essay writing skills. Among these aspects, the Organization component has the strongest effect with a coefficient of 0.396 with the intercept, labeled as "constant" in the equation, of 5.002, coming next are the Coherence and Cohesion component with 0.258 and the Task response component with 0.247 . However, the teaching method proves to have less effect on students' surface aspects of essay writing skills when the Grammar and sentence structure component has the coefficient of only 0.098 and the Vocabulary component has a negative coefficient of minus 0.083 .

Consequently, the current study would like suggest actively applying critical thinking skills in teaching essay writing skills in order students, especially from Confucius-heritage countries as Vietnam, have opportunities to evaluate the right or wrong ways that a passage is developed, and to be able to compose a good piece of writing under English style. Also, to a certain extent, writing is not a right-or-wrong skill but a good-or-not-good skill. With surface aspects, the matter is maybe right or wrong, but with global aspects, the matter is good or not good. Focusing too much on surface aspects, then, may be changing nothing for students' writing ability when their pieces of writing are not developed under the language written.

\section{REFERENCES}

[1] Anderson, L. W., \&Sosniak, L. A. (1994). Bloom's Taxonomy: A forty year retrospective. Chicago: The University of Chicago Press.

[2] Anderson, L. W., \&Krathwohl, D. R. (2001). A Taxonomy for Learning, Teaching and Assessing: A revision of Bloom's Taxonomy of educational objectives. New York: Longman.

[3] Benjamin, R., \& Chun, M. (2003). A new field of dreams: The collegiate learning assessment project. Association of American College and Universities, 3(4), 16-25.

[4] Cohen, L., Manion, L., \& Morrison, K. (2010). Research Methods in Education.London and New York: Routledge

[5] Creswell, J. W. (2012). Educational research: Planning, conducting, and evaluating quantitative and qualitative research. Boston: Pearson.

[6] Cronbach, L. J. (1971). Test validity. Educational Measurement. Washington DC: American Council on Education.

[7] Fahim, M., \&Ahmadi, H. (2012).Critical thinking, content schemata and EFL readers' comprehension and recall.Journal of Comparative Literature and Culture, 1(2), 23-28.

[8] Fitzpatrick, A. R. (1983). The meaning of content validity.Applied psychological measurement, 7(1), 3-13.

[9] Grabe, W. \& Kaplan, R. B.(1996). Theory and practice of writing. New York: Longman.

[10] Hinds, J. (1987). Reader versus Writer Responsibility: A New Typology. Writing across Languages, 141152.

[11] Kaplan, R. B. (1966). Cultural through patterns in Inter-cultural Education.Language Learning, 16(2), 120.

[12] Krathwohl, D. R. (2002). A Revision of Bloom's Taxonomy.Theory in Practice, 14(4), 212-218.

[13] Leonhard, B. H. (2002). Discoveries in Academic Writing, UK: Heinle\&Heinle.

[14] Loh, C. Y. R., \&Teo, T. C. (2017). Understanding Asian students learning styles, cultural influence and learning strategies. Journal of Education and Social Policy, 7(1), 194-210. 
[15] Roever, C., \&Phakiti, A. (2018). Quantitative methods for second language research.New York and London: Routledge.

[16] Rosenthal, R., \&Rosnow, R. L. (1991). Essentials of behavioral research: Methods and data analysis. McGraw-Hill Publishing Company.

[17] Snedecor, G. W., \& Cochran, W. G. (1989). Statistical Methods. USA: Iowa State University Press

[18] Tapper, J. (2004). Student perceptions of how critical thinking is embedded in a degree program. Higher Education Research and Development, 23(2), 199-222.

[19] Tsui, A. B., \&Ng.M. (2000). Do secondary L2 writers benefit from peer comments? Journal of Second Language Writing, 9(2), 147-170. Retrieved from http://dx.doi.org/10.1016/S1060-3743 (00)00022-9 in Sept 2018.

[20] Vyncke, M. (2012). The concept and practice of critical thinking skills in academic writing: An investigation of international student's perception and writing experiences. London: King's College.

[21] Weigle, S. C. (2002).Assessing Writing, United Kingdom: Cambridge University Press.

[22] Wilson, L. O. (2018). Three domains of learning: Cognitive, Affective, Psychomotor. Retrieved from https://thesecondprinciple.com/instructional-design/threedomainsoflearning/

\section{APPENDIX 1}

Lesson plan (summarizing) for 45-minute teaching the introduction for an essay.

\begin{tabular}{|c|c|c|c|}
\hline 45 minutes & \multicolumn{3}{|c|}{ Aims: instructing students to develop the introduction of an Argumentative essay } \\
\hline Duration & Activities & Objective & On Bloom's taxonomy \\
\hline 10 minutes & $\begin{array}{l}\text { Remind students the format of an } \\
\text { Argumentative essay (which } \\
\text { already was introduced to } \\
\text { students in the two first meetings } \\
\text { of the course). } \\
\text { - parts of the essay } \\
\text { - purpose of each parts } \\
\text { - format of each parts }\end{array}$ & $\begin{array}{l}\text { - help students know the } \\
\text { purposes of Argumentative } \\
\text { essays } \\
\text { - help students know how to } \\
\text { develop an Argumentative } \\
\text { essay } \\
\text { - Can students remember the } \\
\text { information? }\end{array}$ & Remember \\
\hline 03 minutes & Students give topic to discuss & & \\
\hline 05 minutes & $\begin{array}{l}6 \text { students make the outline of } \\
\text { the essay on backboard }\end{array}$ & $\begin{array}{l}\text { - Can students explain the } \\
\text { topic assigned? }\end{array}$ & Understanding \\
\hline 05 minutes & $\begin{array}{l}6 \text { students are randomly asked to } \\
\text { have ideas about the outline on } \\
\text { the backboard }\end{array}$ & $\begin{array}{l}\text { - Can students use the } \\
\text { information instructed in a } \\
\text { new way? }\end{array}$ & Applying \\
\hline 05 minutes & $\begin{array}{l}5 \text { students are asked to write the } \\
\text { first sentence of the introduction } \\
\text { on the blackboard }\end{array}$ & $\begin{array}{l}\text { - } \quad \text { Can students distinguish } \\
\text { between different parts? }\end{array}$ & Applying \\
\hline 10 minutes & $\begin{array}{l}5 \text { students are randomly asked to } \\
\text { give their comments to the } \\
\text { sentences on the blackboard, } \\
\text { focusing on } \\
\text { - grammar and spelling } \\
\text { - restate the topic assigned } \\
\text { - how much easy to write the } \\
\text { next sentences } \\
\text { how much interesting the } \\
\text { sentence is }\end{array}$ & $\begin{array}{l}\text { - Can students justify a } \\
\text { stand or decision? }\end{array}$ & Analyzing Evaluating \\
\hline 05 minutes & $\begin{array}{l}5 \text { different students are randomly } \\
\text { asked to correct the sentences on } \\
\text { the blackboard, based on the } \\
\text { comment given }\end{array}$ & $\begin{array}{l}\text { - Can students create a new } \\
\text { product or point of view? }\end{array}$ & Creating \\
\hline 02 minutes & $\begin{array}{lll}\text { Lecturer } & \text { concludes } & \text { the } \\
\text { introduction } & & \end{array}$ & & \\
\hline
\end{tabular}

\section{APPENDIX 2 -QUESTIONNAIRE}

This questionnaire is designed to explore your points of view towards the teaching method for the skills of writing essays by applying critical thinking skills in teaching technique to enhance students' writing skills. 
We hope that you take time to study the items in the questionnaire and answer them by tick $(\sqrt{ })$ in the relevant boxes, which are appropriate most to your idea. Your responses will surely help us improve our teaching method to benefit other students more and more.

Your responses will be used and only be used to study your points of view towards our teaching method for the sills of writing paragraphs and essays and will surely not be used for any other purposes.

In this questionnaire, from Item \#01 to Item \#20, the response options are formulated as follows:

\begin{tabular}{|l|l|l|}
\hline 1 - Strongly disagree & $4-$ Neutral & 5 - Moderately agree \\
2 - Disagree & & 6 - Agree \\
$3-$ Moderately disagree & & 7 -Strongly agree \\
\hline
\end{tabular}

Please choose only ONE option among seven options for each item by ticking $(\sqrt{ })$ the relevant number, which is most appropriate to your feeling. For the conveniences of the study, we hope you will response to all items in this questionnaire.

In the following items, the term "portfolio assessment" means the four assessments you have to done in the course.

\begin{tabular}{|c|c|c|c|c|c|c|c|c|}
\hline & Items & 1 & 2 & 3 & 4 & 5 & 6 & \\
\hline 1 & $\begin{array}{l}\text { The peer correction activities done with the detailed instruction helps me } \\
\text { understand deeply the organization of an essay. }\end{array}$ & $\square$ & $\square$ & $\square$ & $\square$ & $\square$ & $\square$ & \\
\hline 2 & $\begin{array}{l}\text { The teaching method forces me continue thinking more logical when } \\
\text { developing an essay. }\end{array}$ & $\square$ & $\square$ & $\square$ & $\square$ & $\square$ & $\square$ & \\
\hline 3 & $\begin{array}{l}\text { I know better how to focus on responding to the topic assigned, compared to } \\
\text { the past. }\end{array}$ & $\square$ & $\square$ & $\square$ & $\square$ & $\square$ & $\square$ & \\
\hline 4 & $\begin{array}{l}\text { The teaching method helps me remember better grammar aspects and } \\
\text { sentence structures. }\end{array}$ & $\square$ & $\square$ & $\square$ & $\square$ & $\square$ & $\square$ & ¿ \\
\hline 5 & e course, I am able to develop an essay better with the organization. & $\square$ & $\square$ & $\square$ & $\square$ & $\square$ & $\square$ & $\square$ \\
\hline 6 & $\begin{array}{l}\text { mmar aspects and sentence structures after the course is } \\
\text { ly. }\end{array}$ & $\square$ & $\square$ & $\square$ & $\square$ & $\square$ & $\square$ & 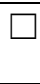 \\
\hline 7 & $\begin{array}{l}\text { an essay are more coherent when developing an essay } \\
\text { compared to the past. }\end{array}$ & $\square$ & $\square$ & $\square$ & $\square$ & $\square$ & $\square$ & $\square$ \\
\hline 8 & gnificantly after the course. & $\square$ & $\square$ & $\square$ & $\square$ & $\square$ & $\square$ & $\square$ \\
\hline 9 & Н & $\square$ & $\square$ & $\square$ & $\square$ & $\square$ & $\square$ & 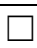 \\
\hline 10 & 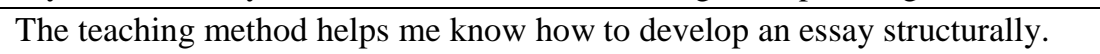 & $\square$ & $\square$ & $\square$ & $\square$ & $\square$ & $\square$ & $\square$ \\
\hline 11 & $\begin{array}{l}\text { s with different ways to tell readers my feelings } \\
\text { exactly. }\end{array}$ & $\square$ & $\square$ & $\square$ & $\square$ & $\square$ & $\square$ & $\square$ \\
\hline 12 & s to develop an academic piece of writing. & $\square$ & $\square$ & $\square$ & $\square$ & $\square$ & $\square$ & \\
\hline 13 & $\begin{array}{l}\text { My thoughts are developed more logically when approaching any topic } \\
\text { assigned. }\end{array}$ & $\square$ & $\square$ & $\square$ & $\square$ & $\square$ & $\square$ & \\
\hline 14 & se of Academic writing helps me aware better the organization of & $\square$ & $\square$ & $\square$ & $\square$ & $\square$ & $\square$ & $\square$ \\
\hline 15 & 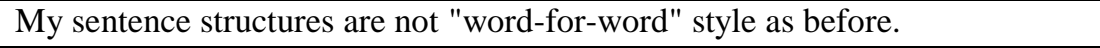 & $\square$ & $\square$ & $\square$ & $\square$ & $\square$ & $\square$ & ᄃ \\
\hline 16 & way & $\square$ & $\square$ & $\square$ & $\square$ & $\square$ & $\square$ & L \\
\hline 17 & Н Hav & $\square$ & $\square$ & $\square$ & $\square$ & $\square$ & $\square$ & \\
\hline 18 & guage corresponding to the & $\square$ & $\square$ & $\square$ & $\square$ & $\square$ & $\square$ & \\
\hline 19 & $\begin{array}{l}\text { e course, I gave up my habit of "beating about the bust" when } \\
\text { ng an essay. }\end{array}$ & $\square$ & $\square$ & $\square$ & $\square$ & $\square$ & $\square$ & 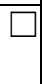 \\
\hline 20 & $\begin{array}{l}\text { After the course, I understand how to prove my ideas concisely and chiefly } \\
\text { to convince readers. }\end{array}$ & $\square$ & $\square$ & $\square$ & $\square$ & $\square$ & $\square$ & 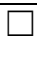 \\
\hline 21 & $\begin{array}{l}\text { The peer correction activities help me understand deeply the essay } \\
\text { organization. }\end{array}$ & $\square$ & $\square$ & $\square$ & $\square$ & $\square$ & $\square$ & 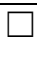 \\
\hline 22 & y sentence structure is more academic. & $\square$ & $\square$ & $\square$ & $\square$ & $\square$ & $\square$ & \\
\hline 23 & $\begin{array}{l}\text { I am interested in my improvement on the ways to link sentences in the } \\
\text { essay to express my ideas coherently. }\end{array}$ & $\square$ & $\square$ & $\square$ & $\square$ & $\square$ & $\square$ & \\
\hline 24 & & $\square$ & $\square$ & $\square$ & $\square$ & $\square$ & $\square$ & \\
\hline 25 & $\begin{array}{l}\text { The pressure of being deducted the scores for each assignment actually } \\
\text { helps me keep in mind better how to develop a paragraph, an essay to }\end{array}$ & $\square$ & $\square$ & $\square$ & $\square$ & $\square$ & $\square$ & \\
\hline
\end{tabular}




\begin{tabular}{|c|c|c|c|c|c|c|c|c|}
\hline & convince readers. & & & & & & & \\
\hline 26 & I focus more on using many syllable words than simple words. & $\square$ & $\square$ & $\square$ & $\square$ & $\square$ & $\square$ & $\square$ \\
\hline 27 & $\begin{array}{l}\text { With peer correction activities, I learn different ways to address a problem } \\
\text { brought up in the topic assigned. }\end{array}$ & $\square$ & $\square$ & $\square$ & $\square$ & $\square$ & $\square$ & $\square$ \\
\hline 28 & Compared to the past, my ideas to develop an essay are more logical. & $\square$ & $\square$ & $\square$ & $\square$ & $\square$ & $\square$ & $\square$ \\
\hline 29 & After the course, I improved nothing relating to the essay structures. & $\square$ & $\square$ & $\square$ & $\square$ & $\square$ & $\square$ & $\square$ \\
\hline 30 & $\begin{array}{l}\text { The use of grammar aspects and sentence structures focuses more on } \\
\text { expressing my feelings. }\end{array}$ & $\square$ & $\square$ & $\square$ & $\square$ & $\square$ & $\square$ & $\square$ \\
\hline 31 & $\begin{array}{l}\text { The teaching method used in the course improved my academic writing } \\
\text { skills? }\end{array}$ & $\square$ & $\square$ & $\square$ & $\square$ & $\square$ & $\square$ & $\square$ \\
\hline
\end{tabular}

AUTHORS' BIOGRAPHY

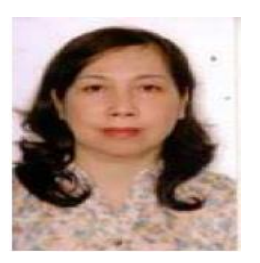

Nguyen Thi Kieu Thu, Ph.D, Dean of the Faculty of English Language, Ho Chi Minh City University of Technology (HUTECH), Vietnam. Research interests: Translation studies, Teaching methodology, and Cognitive linguistics.

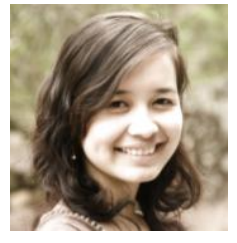

Vo Tran Minh Hieu Lecturer of English at the Faculty of English Language, Ho Chi Minh City University of Technology (HUTECH), Vietnam. Research interests: Teaching methodology, and Cognitive linguistics

Citation: Nguyen Thi Kieu Thu, Vo Tran Minh Hieu. Applying Critical Thinking Skills to Improve Students' Essay Writing Skills" International Journal on Studies in English Language and Literature (IJSELL), vol 7, no. 5, 2019, pp. 27-37. doi:http://dx.doi.org/10.20431/2347-3134.0705003.

Copyright:@ 2019 Authors. This is an open-access article distributed under the terms of the Creative Commons Attribution License, which permits unrestricted use, distribution, and reproduction in any medium, provided the original author and source are credited. 